\title{
CT-guided stereotactic microsurgical resection of cerebral mass lesions
}

\section{Intrakranial kitlelerin bilgisayarlı tomografi rehberliğinde sterotaktik mikrocerrahi rezeksiyonu}

Mehmet ERŞAHIN, Mehmet Sabri GÜRBÜZ, Numan KARAARSLAN, Ahmet Ferruh GEZEN

\begin{abstract}
Stereotactic microsurgical techniques allow for the precise localization and resection of lesions in critical areas of cortex or deep within the brain and minimize operative exposure to the surrounding tissues. This study presents our experience with CT-guided stereotactic microsurgical resection of cerebral lesions using the Leksell frame. A total of 42 patients undergoing computerized tomography guided stereotactic microsurgical resection of cerebral lesions between June 2000 and September 2017 were included in the study. Clinical, radiological, histological and follow-up data were retrospectively evaluated. Pre-and post-operative general status of the patients was assessed by Karnofsky Performance Scale (KPS). Except for the subjects with high-grade gliomas, complete resection could be accomplished in all cases. Of the 24 cases with convulsions, a complete cessation of epileptic attacks was attained in 20 and a decrease in their number and frequency was noted in 4 cases. Overall, 20 patients had no change in the KPS score, while 28 patients had increased and two had decreased KPS scores. No postoperative mortality occurred. CT-guided stereotactic microsurgical craniotomy is a safe, reliable and effective technique, which is particularly useful for the surgical treatment of small, benign cranial lesions and cerebral metastases.
\end{abstract}

Keywords: Stereotactic surgery, microsurgery, cerebral lesion, Leksell frame, computerized tomography öz

Stereotaktik mikrocerrahi teknik beynin derin ya da yüzeyel kortikal alanlarındaki kitlelerin doğru hedeflenmesine ve yeterli eksizyonuna olanak tanır ve çevre dokuların cerrahiden etkilenimini en aza indirir. Çalışmamı Leksell çerçeve kullanılarak stereotaktik yöntemle bilgisayarlı tomografi (BT) klavuzluğunda mikrocerrahi rezeksiyonu yapılan intrakranial kitle tanılı olguları kapsamaktadır. Temmuz 2000 ve Eylül 2017 arasında stereotaktik mikrocerrahi rezeksiyonu yapılan toplam 42 hasta çalışmaya alınmıştır. Klinik, radyolojik, histopatolojik veriler ve takip bilgileri retrospektif olarak incelendi. Hastaların ameliyat öncesi ve sonrası klinik durumları Karnofsky Performans Skalası (KPS) kullanılarak değerlendirildi. Yüksek gradeli glioma tanısı alan olgular dışındaki tüm olgularda total rezeksiyon yapılabildi. Nöbet yakınması olan 24 hastanın 20'sinde nöbetler tamamen kontrol altına alındı, 4 olguda ise epileptik atakların sayısında azalma sağlandı. Genel olarak, hastaların 20'sinde KPS skoru aynı kalmış, 28 olguda KPS skorunda artış, 2 olguda ise KPS skorunda azalma gözlenmiştir. Ameliyat sonrası mortalite saptanmamıştır. BT klavuzluğunda yapılan stereotaktik mikrocerrahi rezeksiyon özellikle küçük ve benign kraniyal lezyonlarla serebral metastazların rezeksiyonunda güvenli ve etkin bir tekniktir.

Anahtar kelimeler: Stereotaktik cerrahi, mikrocerrahi, serebral lezyon, Leksell çerçeve, bilgisayarlı tomografi

\section{INTRODUCTION}

Stereotactic techniques were initially developed for experimental purposes and anatomic localisation studies $^{1}$. Robert Henry Clarke and Victor Horsley originally described the stereotactic method in 1906. They defined cartesian coordinates and studied accessing subcortical structures using a three-dimensional positioning device with the same coordinate system ${ }^{2,3}$.
Despite Clarke's suggestion to use stereotaxis for the treatment of brain tumors, Horsley did not consider applications beyond the laboratory, and human use in subcortical stereotaxis came into practice only after Spiegel and Wycis's proposal to apply stereotaxis in the management of human brain neoplasms ${ }^{2-4}$. Meanwhile, Leksell established the basis of a novel system combining the cartesian system with other systems, which consisted of an apparatus fixed to

Received: 09.01.2018

Accepted: 17.04 .2018

${ }^{1}$ Department of Neurosurgery, Istanbul Medeniyet University Medical Faculty, Istanbul, Turkey

2Department of Neurosurgery, Namık Kemal University Medical Faculty, Tekirdağ, Turkey

Yazışma adresi: Mehmet Erşahin, Department of Neurosurgery, Istanbul Medeniyet University Medical Faculty, Istanbul, Turkey

e-mail: drmehmetersahin@gmail.com 
the cranium and a mobile arch-quadrant system attached to it ${ }^{5}$.

Guiot et al. ${ }^{6,7}$ and Riechert and Mundinger ${ }^{8}$ were the first investigators to introduce open stereotactic craniotomy, which was then enjoyed broader applications and further refinements owing to the advances in the field of medical imaging such as computerized tomography ${ }^{9}$ and magnetic resonance imaging ${ }^{10}$. Current image-guided stereotactic procedures include biopsy $^{11-15}$, cyst aspiration ${ }^{16,17}$, focal irradiation ${ }^{18,19}$, and hematoma evacuation ${ }^{20-22}$, neuroaugmentation ${ }^{22,23}$, stereotactic robotic microsurgery ${ }^{24-26}$ and neural transplantation ${ }^{27,28}$. These techniques facilitate precise localization and resection of lesions in eloquent regions of brain and help minimize operative injury to the surrounding tissues.

In this study, we report our experience with CTguided stereotactic microsurgical resection of cerebral lesions using the Leksell frame and discuss the indications, results and limitations of the technique under the light of current literature.

\section{MATERIALS and METHODS}

\section{Patients}

A total of 42 patients undergoing stereotactic microsurgical resection of cerebral lesions guided by computerized tomography between June 2000 and September 2017 at the Neurosurgery Departments of Haydarpasa and Göztepe Training Hospitals were included in this study. Informed consents were obtained from the patients. Clinical, radiological and histological data as well as the records of pre-operative and post-operative neurological examinations, complications, and follow-up period were retrospectively evaluated. Stereotactic biopsies, brachytherapies, Ommaya reservoir applications, and cyst aspirations were not included.

\section{Preoperative Clinical Assessments}

Preoperative clinical, radiological and neurological data were examined and all patients underwent a comprehensive evaluation by a medical team, which included a neurosurgeon, neuropathologist, neuroradiologist, and neuroanesthesiologist. Past or current history of bleeding diathesis was evaluated by an internal medicine specialist, and the high-risk patients were excluded. Patients on antithrombocytic treatment were instructed to stop medication at least seven days before the procedure. Pre- and postoperative general status of the patient was assessed by Karnofsky Performance Scale (KPS). Procedures were performed under general anesthesia.

\section{Operative technique}

Leksell Stereotactic system (Elekta-Sweden) and the General Electric CT scanner were used for the stereotactic procedures (Fig 1). The stereotactic frame was placed under local anesthesia and attention was paid to the insertion sites of the pins to avoid encroachment upon the operative area. After calculation of the target coordinates, the patient was taken to the operating room and the procedure was performed under general anesthesia. A small patch of hair was shaved over the operative site and the entire head and the frame were placed and draped in a sterile fashion. Then the standard microsurgical stereotactic procedure was performed as previously described ${ }^{29}$ 32. A Sedan needle was used as a guide to determine the target area of craniotomy. For this purpose, a linear scalp incision of 5 to $6 \mathrm{~cm}$ in length was made over the target site and then a $3 \mathrm{~cm}$ craniotomy was performed using a high-speed drill. In order to expose the cortical surface a cruciate-shaped opening on the dura was made, which was followed by the resection of the lesion by the operating microscope

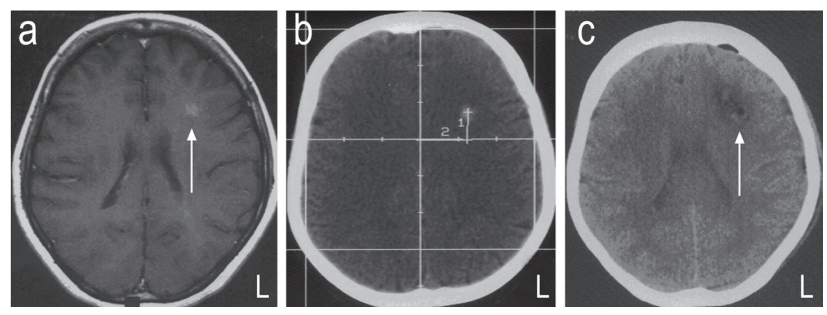

Figure 1. An example image of a patient with left frontal subcortical cavernoma. AxialT1-weighed MRI before operation (a) and CT images during (b) and after (c) stereotactic intervention. The image obtained during the operation indicates the stereotactic coordinates. L, left. Arrow indicates the lesion (a) and location of the removed lesion in postoperative image (c). ${ }^{11}$ 
using standard microsurgical techniques. For superficial lesions, sedan biopsy needle was used to confirm the precision of the surgical incision and verification of the approach. Deep-seated lesions on the other hand were resected by means of a stereotactically directed cylindrical retractor that is inserted through a dilated cortical and subcortical white matter incision. The incision was made with the guidance of sedan needle and dilated using a retractor-dilator system. A cranial CT was routinely performed within 24 hours after the procedure and repeated when required. Patients with tuberculomas received anti-tuberculous treatment until radiological and clinical cure was achieved.

\section{RESULTS}

Twenty-seven cases (64.3\%) were male and 15 (35.7\%) were female, with a mean age of $46.4 \pm 18.2$ years (range: $10-72$ y). Three subjects $(7.1 \%)$ were in the pediatric age group ( $<15$ years). The most common presentations included convulsions $(n=25$, $59.5 \%$ ) -including one patient with status epilepticus and one patient with intractable seizures- and muscle weakness of the upper and/or lower extremities $(n=13,31.0 \%)$, followed by headache $(n=5,11.9 \%)$, acute hydrocephalus $(n=2,4.8 \%)$, and fever $(n=1$, 2.4\%). Muscle weakness in extremities was the most common sign detected in the neurological examina-

Table 1. Localization of the lesions.

\begin{tabular}{ll}
\hline Feature & $\mathrm{n}(\%)$ \\
\hline Lesion side & \\
Left-sided & $21(50.0 \%)$ \\
Right-sided & $15(35.7 \%)$ \\
Midline (third ventricle) & $2(4.8 \%)$ \\
Solitary mass with bilateral involvement & $3(7.1 \%)$ \\
Bilateral multiple lesions & $1(2.4 \%)$ \\
Localization & \\
Frontoparietal cortex & $15(35.7 \%)$ \\
Frontoparietal & $7(16.7 \%)$ \\
Motor cortex & $5(11.9 \%)$ \\
Parietal & $4(9.5 \%)$ \\
Parietal cortex & $3(7.1 \%)$ \\
Temporal & $3(7.1 \%)$ \\
Frontotemporal & $2(4.8 \%)$ \\
Third ventricle & $2(4.8 \%)$ \\
Frontal & $1(2.4 \%)$ \\
& \\
\hline
\end{tabular}

tion. Localizations and histopathological features of the lesions are shown in Table 1 and Table 2, respectively.

Except for the subjects with high-grade gliomas, complete resection could be accomplished in all cases as confirmed by the postoperative CT and/or MRI scans. Among 24 cases, complete cessation of convulsions was attained in 20 and a decrease in the number and frequency of epileptic attacks was noted in 4 cases.

The total operating time ranged between 2.5 and 4 hours (mean: $3.3 \mathrm{~h}$ ) and the average duration of hospital stay was 3.5 days (range 2-11). Patients were followed-up for an average of $31.4 \pm 31.5$ months (range: 8-132 m). Overall, 20 patients had no change in the KPS score, while 28 patients had increased and two had decreased KPS scores.

One subject experienced postoperative subdural effusion which was successfully managed with steroids, while another had a hematoma in the operation site, which did not cause a mass-effect, and resolved upon conservative monitoring. No patients had infection. Transient neurological deficits occurred in five patients that were mainly self-limited and mild sensory deficits lasting 4-5 days after resection of lesions adjacent to the precentral gyrus. One patient

Table 2. Histopathological diagnosis of the lesions.

\begin{tabular}{ll}
\hline Histopathological diagnosis & $\mathbf{n}(\%)$ \\
\hline Tuberculoma & $6(14.3 \%)$ \\
Cavernoma & $6(14.3 \%)$ \\
Glioblastoma & $5(11.9 \%)$ \\
Adenocarcinoma metastasis & $4(9.5 \%)$ \\
Non-small cell lung cancer metastasis & $4(9.5 \%)$ \\
Undifferentiated carcinoma metastasis & $4(9.5 \%)$ \\
Colloid cyst & $2(4.8 \%)$ \\
Lymphoma & $2(4.8 \%)$ \\
Pyogenic infection & $2(4.8 \%)$ \\
Anaplastic astrocytoma & $1(2.4 \%)$ \\
Pilocytic astrocytoma & $1(2.4 \%)$ \\
Pleomorphic xanthoastrocytomas & $1(2.4 \%)$ \\
Carcinoma metastasis (other than lung cancer) & $1(2.4 \%)$ \\
Dysembryoplastic neuroepithelial tumor & $1(2.4 \%)$ \\
Oligodendroglioma & $1(2.4 \%)$ \\
Small cell carcinoma metastasis & $1(2.4 \%)$ \\
& \\
\hline
\end{tabular}


had severe hemiparesis due to peritumoral edema that resolved almost completely after 2 months of intensive rehabilitation. No postoperative mortality occurred.

\section{DISCUSSION}

Despite advances in the field of neuroimaging, use of $\mathrm{CT}$ or MRI during open surgery continues to present certain difficulties, especially in small or deep-seated lesions of the brain parenchyma. Particularly, small corticosubcortical lesions often do not cause macroscopic changes on the brain surface hindering their detection during surgery. Conversely, stereotactic techniques are able to localize precisely cerebral structures and lesions ${ }^{25,33,34}$. Therefore, stereotactic craniotomy combines this precision with the advantages of open surgery to minimize the possibility of exposure and injury to the surrounding tissues. As compared to simple biopsy, stereotactic craniotomy may increase the accuracy of histopathological diagnosis and provide further therapeutic benefits thaks to the reversal of progressive neurological deficits ${ }^{15,34}$.

Recently stereotactic robotic microsurgery has been developed based on stereotactic surgery with/without frame. Although this system can be used in various areas of neurosurgery, they are expensive and sophisticated systems requiring further equipments. On the other hand, frame-based and CT-guided stereotactic microsurgery is safe and effective in selected cases. Furthermore, this system is more applicable owing to the fact that it is simple and cheap ${ }^{9,13,24-26}$.

Patients with well-demarcated lesions less than 3 $\mathrm{cm}$ in diameter that are deeply localized within the cerebrum, the lesions superficially located near the functional cortex or otherwise difficult to localize are the best candidates for the procedure. The best results have been reported for benign lesions such as tuberculomas $^{16,35}$, cavernomas $^{36}$, and colloid cysts ${ }^{37,38}$; however it is also possible to remove metastatic lesions with desirable consequences ${ }^{39}$. Stereotactic craniotomy does not seem to provide any particular advantages in malignant glioma surgery and thus best outcomes were observed in benign localized lesions such as tuberculomas, cavernomas, and colloid cysts among our participants. In addition, total resection was possible in all subjects with metastasis with good results.

Stereotactic craniotomy requires small and linear scalp incisions (generally $\leq 5-6 \mathrm{~cm}$ in length) and minimal bone removal (about 2.5-3 cm). This limited craniotomy and surgical exposure minimize the risks of postoperative complications and provide earlier wound healing and rapid recovery. The procedures are well tolerated by the patients and they shorten the duration of hospital stay as reflected by the fact that most patients are ready for discharge on postoperative day 2. As compared to conventional craniotomy, the average duration of the total surgical procedure including frame application, stereotactic imaging, surgical planning and craniotomy is longer; however, the actual operation under general anesthesia takes an average of $1.8 \mathrm{~h}$.

Standard surgical techniques are still the recommended mainstay of treatment for the removal of lesions greater than $3.5 \mathrm{~cm}$ in diameter ${ }^{25,40,41}$. In line with this recommendation, none of our patients undergoing stereotactic microsurgical resection had a lesion greater than $3 \mathrm{~cm}$ in diameter.

Following the initial introduction of open stereotactic craniotomy by Guiot et al., ${ }^{6,7}$ and Riechert and Mundinger ${ }^{8}$, this technique has been more widely applied and further refined in recent years with more sophisticated instruments that was pioneered by Kelly et al. ${ }^{30,31}$. Frameless stereotaxy may be considered as an alternative to open stereotactic craniotomy but currently these systems lack the advantages of frame - based systems, particularly for superficial lesions. Furthermore, most of these systems fuse the probe position to a CT image after its placement on or in a particular region. On the other hand, with deeper lesions, the placement of the probe into the brain for the purpose of locating the lesion or choosing the best approach could lead to injury of critical structures that should be avoided ${ }^{42,43}$. 
Rarely, brain shift may present as a problem during stereotactic craniotomy which may lead to a significant loss of reliability of neuro-navigation systems during microsurgical removal of intracranial mass lesions. The course and the severity of brain shift may differ according to special subgroups of supratentorial lesions and it may be difficult to make exact preoperative predictions regarding the brain shift due to the heterogeneous nature of the lesions to be removed and due to the differences between superficial and subcortical areas. Only an intra-operative imaging modality can help overcome this known problem of modern neuronavigation ${ }^{44}$. A significant deal of debate has been continuing on the problem of brain shift during stereotactical craniotomies. Previously, due to the significant concerns about this problem, we placed stainless steel reference balls through a burr-hole and a stereotactically directed probe within a tumoral target volume. However, brain shift probably did not pose a significant problem in our experience due to the following methodological principles that were followed uniformly in all procedures $^{45}$ : (1) the craniotomy was in the least dependent position in the surgical field. The patient's head was positioned in such a way that the arch angle was close to zero; (2) the dura was opened only after the intracranial pressure was lowered by hypocarbia, reverse Trendelenburg position, barbiturates and hyperosmotic agents; (3) the ventricular system was not entered until the peritumoral plane was identified; (4) tumors were not debulked until entire plane was determined around the lesion.

Removal of contrast-enhancing portions of highgrade gliomas with acceptable mortality and morbidity can be accomplished with computer-assisted stereotactic resection ${ }^{32,45-47}$. Similarly, resection was achieved with minimal morbidity in our patients with high-grade glial neoplasms and no contrast-enhanced areas were detected postoperatively.

The resectability of low-grade astrocytomas is closely associated with the histological features of the tumor. These tumors do not exhibit a clear demarcation from the brain parenchyma, which may hamper resection and cause neurological deficits ${ }^{30,45,47}$. In our study group, both of the two patients with low-grade astrocytoma had postoperative neurological deficits, which resolved quickly in one but persisted in the other in the form of a mild-deficit after long-term rehabilitation.

In general, metastatic tumors are well circumscribed and the plane between tumour and edematous brain tissue can be readily identified ${ }^{39}$. In line with these observations, resection did not present any difficulty in our patients with metastatic lesions and no residual mass was detected postoperatively. One subject experienced a transient neurological deficit that resolved completely with anti-edema treatment.

In our patients with small superficial lesions suggesting tuberculoma, we preferred stereotactic microsurgical excision over open biopsy on the basis of the following reasons: (i) possible injury to superficial cortical vessels during closed biopsy for tuberculoma; (ii) greater likelihood of reaching a definitive diagnosis because of the larger sample size obtained by tumoral excision; (iii) provision of symptomatic control (e.g. seizures) and shortened duration of antituberculous treatment ${ }^{16,35,48,49}$. After total resection of the tuberculomas, a complete cessation of convulsions was achieved in all subjects in our study.

For lymphomas, surgical resection is not recommended, and following a definitive diagnosis of lymphoma is made with stereotactic biopsy, chemotherapy and radiotherapy can be initiated ${ }^{50}$. Our lymphoma patients undergoing resection had not presented with a classical radiological appearance.

Stereotactic puncture and antibiotic treatment based on the culture results are the preferred method of management in pyogenic cerebral abscesses ${ }^{51}$. Similarly, in our unit, the initial therapeutic approach for cerebral abscesses consists of treatment with stereotactic punctures, and two cases in our study with cerebral abscesses underwent resection due to a false mass image and firm capsular structure detected during operation. In addition, two patients were 
operated due to a diagnosis of colloidal cyst without any complications.

Stereotactic craniotomy technique shortens operative time compared to conventional craniotomy, and gives the chance of radical treatment of the lesion ${ }^{13,38}$. Complication rates of stereotactic craniotomy are similar to those observed in conventional craniotomy ${ }^{29,34,36}$. Absence of infection among our patient group may be explained by the comprehensive pre-operative assessments for possible foci of infection, treatment of infections before the procedure, prophylactic use of intraoperative antibiotics, and improved wound care. No patients had hemorrhage that required surgical intervention. One patient had a hematoma, which was resolved following conservative observation. Absence of hematomas requiring surgical drainage is probably associated with the preoperative assessment of patients in terms of bleeding diathesis by an internal medicine specialist, discontinuation of anti-aggregating agents, exclusion of patients with thrombocytopenia, and good perioperative bleeding control. No mortality was observed.

In conclusion, CT-guided stereotactic microsurgical craniotomy is a safe, reliable and effective technique, which is particularly useful for the surgical treatment of small, benign cranial lesions and cerebral metastases. It allows for the precise excision of cerebral lesions through small bony openings and planned transcortical trajectories; and ensures accurate localization while minimizing the risk of injury to adjacent tissues. However, despite the abundant tissue sampling for histopathological examination, it is currently relatively inapplicable to the treatment of malignant gliomas due to their infiltrative nature. With further advances, it may be possible to perform more precise debulking with minimal risk of injury to the surrounding normal tissues.

\section{REFERENCES}

1. Gabriel EM. Historical development of stereotactic frames. In: Gildenberg PL, Tasker RR, eds. Stereotactic and Functional Neurosurgery. Second ed. 1998:29-49.
2. Clarke RH, Horsley V. THE CLASSIC: On a method of investigating the deep ganglia and tracts of the central nervous system (cerebellum). Br Med J 1906:1799-1800. Clin Orthop Relat Res. 2007;463:3-6.

3. Horsley V, Clarke RH. The structure and functions of the cerebellum examined by a new method. Brain. 1908;31:45-124. https://doi.org/10.1093/brain/31.1.45

4. Spiegel EA, Wycis HT, Marks M, et al. Stereotaxic Apparatus for Operations on the Human Brain. Science. 1947;106:349-50. https://doi.org/10.1126/science.106.2754.349

5. Leksell L. A stereotaxic apparatus for intracerebral surgery. Acta Chir Scand. 1949;99:229-33.

6. Guiot G, Rougerie J, Sachs M, et al. Stereotaxic location of deep intracerebral vascular malformations. Neurochirurgie. 1960;6:266-8.

7. Guiot G, Rougerie J, Sachs M, et al. Stereotactic localization of deep vascular intracerebral malformations. Sem Hop. 1960;36:1134-43/SP.

8. Riechert T, Mundinger F. Combined Stereotaxic Operation for Treatment of Deep-Seated Angiomas and Aneurysms. J Neurosurg. 1964;21:358-63.

https://doi.org/10.3171/jns.1964.21.5.0358

9. Maroon JC, Bank WO, Drayer BP, et al. Intracranial biopsy assisted by computerized tomography. J Neurosurg. 1977; 46:740-4.

https://doi.org/10.3171/jns.1977.46.6.0740

10. Leksell L, Leksell D, Schwebel J. Stereotaxis and nuclear magnetic resonance. J Neurol Neurosurg Psychiatry. 1985;48:14-8.

https://doi.org/10.1136/jnnp.48.1.14

11. Ersahin M, Karaaslan N, Gurbuz MS, et al. The safety and diagnostic value of frame-based and CT-guided stereotactic brain biopsy technique. Turk Neurosurg. 2011;21:582-90. https://doi.org/10.5137/1019-5149.JTN.4656-11.1

12. Can SM, Turkmenoglu ON, Tanik C, et al. Computerized Tomography-Guided Stereotactic Biopsy of Intracranial Lesions: Report of 500 Consecutive Cases. Turk Neurosurg. 2017;27:395-400.

13. Xu K, Hai J. The clinical study of stereotactic microsurgery. Cell Biochem Biophys. 2014;69:259-63. https://doi.org/10.1007/s12013-013-9793-3

14. Savas A, Kanpolat Y. Safety and efficacy of frameless and frame-based intracranial biopsy techniques. Acta Neurochir (Wien). 2008;150:737. https://doi.org/10.1007/s00701-008-1612-z

15. Calisaneller T, Ozdemir O, Ozger O, et al. The accuracy and diagnostic yield of computerized tomography guided stereotactic biopsy in brain lesions. Turk Neurosurg. 2008;18:17-22.

16. Ersahin M, Hakan T, Ayan E, et al. Diagnostic and therapeutic role of CT-guided stereotactic surgery in the management of intracranial tuberculomas. Turk Neurosurg. 2010;20:295-302. https://doi.org/10.5137/1019-5149.JTN.3071-10.1

17. Park WH, Jang IS, Kim CJ, et al. Gamma knife radiosurgery after stereotactic aspiration for large cystic brain metastases. J Korean Neurosurg Soc. 2009;46:360-4. https://doi.org/10.3340/jkns.2009.46.4.360

18. Marko NF, Suh JH, Chao ST, et al. Gamma knife stereotactic radiosurgery for the management of incidentally-identified brain metastasis from non-small cell lung cancer. J Neurooncol. 2011.

https://doi.org/10.1007/s11060-011-0553-1

19. Steiner L, Lindquist C, Adler JR, et al. Clinical outcome of radiosurgery for cerebral arteriovenous malformations. J Neurosurg. 1992;77:1-8. 
https://doi.org/10.3171/jns.1992.77.1.0001

20. Amano K, Kawamura H, Tanikawa $T$, et al. Surgical treatment of hypertensive intracerebral haematoma by CT-guided stereotactic surgery. Acta Neurochir Suppl (Wien). 1987;39:41-4. https://doi.org/10.1007/978-3-7091-8909-2_12

21. Barlas O, Karadereler S, Bahar S, et al. Image-guided keyhole evacuation of spontaneous supratentorial intracerebral hemorrhage. Minim Invasive Neurosurg. 2009;52:62-8. https://doi.org/10.1055/s-0028-1104610

22. Hosobuchi Y, Adams JE, Linchitz R. Pain relief by electrical stimulation of the central gray matter in humans and its reversal by naloxone. Science. 1977;197:183-6. https://doi.org/10.1126/science.301658

23. Gildenberg PL. History of neuroaugmentative procedures. Neurosurg Clin N Am. 2003;14:327-37, v. https://doi.org/10.1016/S1042-3680(03)00012-3

24. Faria C, Erlhagen W, Rito M, et al. Review of Robotic Technology for Stereotactic Neurosurgery. IEEE Rev Biomed Eng. 2015;8:125-37. https://doi.org/10.1109/RBME.2015.2428305

25. Fomenko A, Serletis D. Robotic Stereotaxy in Cranial Neurosurgery: A Qualitative Systematic Review. Neurosurgery. 2017. https://doi.org/10.1093/neuros/nyx576

26. Miller BA, Salehi A, Limbrick DD, Jr., et al. Applications of a robotic stereotactic arm for pediatric epilepsy and neurooncology surgery. J Neurosurg Pediatr. 2017;20:364-70. https://doi.org/10.3171/2017.5.PEDS1782

27. Donovan T, Fryer TD, Pena A, et al. Stereotactic MR imaging for planning neural transplantation: a reliable technique at 3 Tesla? Br J Neurosurg. 2003;17:443-9. https://doi.org/10.1080/02688690310001613844

28. Hitchcock E. Stereotactic neural transplantation. Stereotact Funct Neurosurg. 1994;62:120-33. https://doi.org/10.1159/000098607

29. Cosgrove GR, Steiner L. Stereotactic microsurgical resection of cerebral lesions. Stereotact Funct Neurosurg. 1993;61:182-94. https://doi.org/10.1159/000100636

30. Kelly PJ. Volumetric stereotactic surgical resection of intraaxial brain mass lesions. Mayo Clin Proc. 1988;63:1186-98. https://doi.org/10.1016/S0025-6196(12)65405-6

31. Kelly PJ, Goerss SJ, Kall BA. The stereotaxic retractor in computer-assisted stereotaxic microsurgery. Technical note. J Neurosurg. 1988;69:301-6. https://doi.org/10.3171/jns.1988.69.2.0301

32. Kelly PJ, Kall BA, Goerss SJ. Results of computed tomographybased computer-assisted stereotactic resection of metastatic intracranial tumors. Neurosurgery. 1988;22:7-17. https://doi.org/10.1227/00006123-198801000-00002

33. Pessina F, Navarria P, Cozzi L, et al. Role of Surgical Resection in Patients with Single Large Brain Metastases: Feasibility, Morbidity, and Local Control Evaluation. World Neurosurg. 2016;94:6-12. https://doi.org/10.1016/j.wneu.2016.06.098

34. Rachinger W, Oehlschlaegel F, Kunz M, et al. Cystic Craniopharyngiomas: Microsurgical or Stereotactic Treatment? Neurosurgery. 2017;80:733-43.

35. Rajshekhar V, Chandy MJ. CT-guided stereotactic surgery in the management of intracranial tuberculomas. Br J Neurosurg. 1993; 7:665-71. https://doi.org/10.3109/02688699308995096

36. Davis DH, Kelly PJ. Stereotactic resection of occult vascular malformations. J Neurosurg. 1990;72:698-702. https://doi.org/10.3171/jns.1990.72.5.0698
37. Abernathey CD, Davis DH, Kelly PJ. Treatment of colloid cysts of the third ventricle by stereotaxic microsurgical laser craniotomy. J Neurosurg. 1989;70:525-9. https://doi.org/10.3171/jns.1989.70.4.0525

38. Cabbell KL, Ross DA. Stereotactic microsurgical craniotomy for the treatment of third ventricular colloid cysts. Neurosurgery. 1996;38:301-7.

https://doi.org/10.1097/00006123-199602000-00013

39. Tobler WD, Stanley M. Stereotactic resection of brain metastases in eloquent brain. Stereotact Funct Neurosurg. 1994;63:38-44. https://doi.org/10.1159/000100289

40. Bekar A, Bilgin H, Korfali G, et al. Minimally invasive awake craniotomy using Steiner-Lindquist stereotactic laser guidance. Minim Invasive Neurosurg. 2009;52:176-9. https://doi.org/10.1055/s-0029-1239503

41. Kelly PJ. Stereotactic craniotomy. Neurosurg Clin N Am. 1990;1:781-99.

42. Barnett GH, Kormos DW, Steiner CP, et al. Intraoperative localization using an armless, frameless stereotactic wand. Technical note. J Neurosurg. 1993;78:510-4. https://doi.org/10.3171/jns.1993.78.3.0510

43. Kato A, Yoshimine T, Hayakawa T, et al. A frameless, armless navigational system for computer-assisted neurosurgery. Technical note. J Neurosurg. 1991;74:845-9. https://doi.org/10.3171/jns.1991.74.5.0845

44. Reinges $\mathrm{MH}$, Nguyen $\mathrm{HH}$, Krings $\mathrm{T}$, et al. Course of brain shift during microsurgical resection of supratentorial cerebral lesions: limits of conventional neuronavigation. Acta Neurochir (Wien). 2004;146:369-77; discussion 377. https://doi.org/10.1007/s00701-003-0204-1

45. Lozano AM, Gildenberg PL, Tasker RR. Textbook of Stereotactic and Functional Neurosurgery. Second ed. Berlin: Springer, 2009. https://doi.org/10.1007/978-3-540-69960-6

46. Devaux BC, O’Fallon JR, Kelly PJ. Resection, biopsy, and survival in malignant glial neoplasms. A retrospective study of clinical parameters, therapy, and outcome. J Neurosurg. 1993;78:767-75. https://doi.org/10.3171/jns.1993.78.5.0767

47. Kelly PJ, Kall B, Goerss S, et al. Precision resection of intraaxial CNS lesions by CT-based stereotactic craniotomy and computer monitored CO2 laser. Acta Neurochir (Wien). 1983;68:1-9. https://doi.org/10.1007/BF01406196

48. Chandy MJ, Rajshekhar V, Ghosh S, et al. Single small enhancing CT lesions in Indian patients with epilepsy: clinical, radiological and pathological considerations. J Neurol Neurosurg Psychiatry. 1991;54:702-5. https://doi.org/10.1136/jnnp.54.8.702

49. Poonnoose SI, Rajshekhar V. Rate of resolution of histologically verified intracranial tuberculomas. Neurosurgery. 2003;53:873-8; discussion 878-9. https://doi.org/10.1227/01.NEU.0000083553.25421.6F

50. Foppoli M, Ferreri AJ. Treatment of primary central nervous system lymphoma: recent advances. Recenti Prog Med. 2010;101:376-80.

51. Kutlay M, Colak A, Yildiz S, et al. Stereotactic aspiration and antibiotic treatment combined with hyperbaric oxygen therapy in the management of bacterial brain abscesses. Neurosurgery. 2008;62(Suppl 2):540-6. https://doi.org/10.1227/01.neu.0000316257.21478.5b 